\title{
GASTROINTESTINAL PARASITE INFECTION ON BALI CATTLE RAISED IN SEMI-INTENSIVE FARMING SYSTEM IN DOMPU, SUMBAWA ISLAND: A PRELIMINARY STUDY
}

\author{
Made Sriasih $^{1 *}$, Oscar Yanuarianto ${ }^{1}$, Dahlanuddin ${ }^{1}$, and William Ernest Pomroy ${ }^{2}$ \\ ${ }^{1}$ Animal Science Faculty, Mataram University, Jalan Majapahit No. 62 Mataram, \\ Nusa Tenggara Barat, Indonesia, 83125 \\ ${ }^{2}$ Institute of Veterinary, Animal and Biomedical Sciences, Massey University, Tennent Drive, Massey \\ University Palmerston North 4474 New Zealand \\ *Corresponding author: madesriasihphd@unram.ac.id
}

\begin{abstract}
To date, there are very few studies have been carried out on the effect of parasite infection on Bali cattle, and more importantly, there is no published data on the epidemiology of worm infections on Bali cattle in the island of Sumbawa, Indonesia. This research aimed to undertake a preliminary study on gastrointestinal (GI) parasitic infection on Bali cattle raised under semiintensive farming system in five different sites in district of Dompu, Sumbawa island. Fecal samples of 76 Bali cattle, from three farmer groups namely site number 1, 4 and 5, were collected, processed and examined under a microscope, with 100x magnification, for egg fecal counting or oocyst fecal counting using the modified McMaster technique. The number of eggs/oocysts observed was then determined and identified. The results show that the eggs/oocysts ranged from 50-14800. The types of GI parasites identified were Strongyloides $\mathrm{sp}$, Strongyle sp, Toxocara sp, Trichuris $\mathrm{sp}$, and Coccidia. Coccidia oocyst is a type of parasite which was found with the highest percentage of $23.68 \%$ followed by Strongyle sp. $(18.42 \%)$ and Toxocara sp. $(10.52 \%)$. The overall prevalence of GI parasitic infection in cattle accounted for $43.42 \%$. Young calves (0-3 months old) was more susceptible to GI parasitic infection among other age groups. This preliminary data could be used as a basic data on gastrointestinal parasitic infection in Dompu district. These results may also indicate the need to develop control strategies aiming at lowering the gastrointestinal parasitism.
\end{abstract}

Keywords: Gastrointestinal parasite, Dompu, Bali cattle, Semi-intensive farming

\section{INTRODUCTION}

Bali cattle (Bos javanicus) are a species of cattle that are found distributed across several islands in Indonesia in particular, with small numbers in neighbouring countries. To date very little has been published on the endemic diseases of this particular cattle species in Indonesia.
Gastrointestinal (GI) parasite infection of the ruminant livestock remains one of the major threats to the development of small and large ruminant livestock in tropical countries including Indonesia. Gastrointestinal nematode infestation of cattle shows a very high prevalence rate and is a problem that often does not get the attention of farmers in 
Indonesia. A survey carried out in several animal markets in Indonesia shows that $90 \%$ of cattle and buffaloes were positive of helminthiasis (Abidin, 2002). A survey of internal parasites of Bali cattle in the Bima district of West Nusa Tenggara (NTB) on the island of Sumbawa (Astiti et al. 2011) shows that $81.1 \%$ (120 out of 148 samples) of Bali cattle examined were infected by internal parasites. However, there was no information on the intensity of infection of these parasites.

The present study was undertaken in the Dompu district, located in the central part of Sumbawa Island, NTB. The southern side of this district is directly adjacent to the Indonesian Ocean, while in the other parts it is bordered by Saleh Bay in the Southwest and the Flores Sea in the north. Administratively, Dompu district is divided into 8 (eight) subdistricts with an area of $2,324.55 \mathrm{~km} 2$, and is geographically located between $117^{\circ} 42$ '$118^{\circ} 30^{\prime}$ East Longitude and $8^{\circ} 06^{\prime}-9^{\circ} 05^{\prime}$ South Latitude. In Dompu farmers raise their cattle using a traditional semi-intensive farming system where breeding cows are free range, often on communal grazing areas, but older animals are fattened in some form of dry lot and hand fed. The district of Dompu has been established by the Ministry of Agriculture as a cattle development area in an effort to make NTB an important source of Bali cattle breeding. Thus, the objective of the current study was to determine the prevalence of GI parasitic infection in Bali cattle raised under system in district of Dompu, Sumbawa island. The resulting data may provide baseline knowledge of infection level in this district and may support government policy in an effort to develop control strategies.

\section{MATERIALS AND METHODS}

\section{Sample preparation and sampling location}

Faecal samples from 76 cattle were taken randomly from Bali cattle from three out of five farmer groups in Dompu district which are part of the Innovative Farming System and Capability Activity (IFSCA) project of Massey University and Mataram University. These sites were located in Woja subdistrict (site No. 1), Manggelewa subdistrict (site No. 4) and Kempo subdistrict (site No. 5). Samples were obtained per rectum and then kept at $4^{0} \mathrm{C}$ and taken to the Parasitology laboratory for parasitic examination.

\section{Quantitative analysis using the modified McMaster technique}

Fecal samples were analyzed for the presence of helminth eggs and protozoan oocysts using the modified McMaster technique (Stafford et al., 1994). In brief, $2 \mathrm{~g}$ of faeces was mixed with $28 \mathrm{ml}$ of saturated $\mathrm{NaCl}$ (specific gravity 1.2) until blended and then filtered using a tea strainer. Subsequently, the filtrate was mixed and the 
two chambers of the McMaster slide (Twochamber green rid Mc Master slide, Chalex, LLC Vetslides.com) were filled using a transfer pipette. The chambers were then incubated for $10 \mathrm{~min}$ at room temperature to allow parasite eggs to float to the underside of the top layer of each chamber. Observation was carried out, within an hour of filling the slide, using a microscope with 100x magnification. The volume counted within each of two McMaster chambers is $0.15 \mathrm{ml}$ (total $0.3 \mathrm{ml}$ ) so this approach has a multiplication factor of $100 \mathrm{X}$ for the count in $2 \mathrm{~g}$ of faeces or $50 \mathrm{X}$ to express the count as eggs/g or oocysts/g.

\section{Gastrointestinal parasite identification}

Gastrointestinal parasites observed under the microscope were identified based on book 'Helminth Parasites of Ruminants' (Hansen and Perry, (www.fao.org/wairdocs/ILRI/) to classify the egg type.

\section{Data analysis}

The results of the research were analyzed descriptively.

\section{RESULTS AND DISCUSSION}

Gastrointestinal parasitic infection still remains a problem in cattle producing countries of the world. This parasitic infection in cattle and other ruminants cause diseases of major socio-economic importance worldwide.

The current financial and agriculture losses caused by worm infections have a substantial impact on farm profitability. Losses caused by worm infections in the United States, for example, have accounted for around $\$ 330$ million USD per year (Seo et al., 2015). In the tropical region with poor management and poor nutrition practices, the losses are expected to be even higher due to favorable environment condition for the transmission of infection.

Studies that can help quantify economic losses due to GI parasitic infection are needed, especially in smallholder farming systems in developing countries. As parasite infections may cause disease with clinical or without clinical symptoms that indirectly contribute to economic losses, the most important thing that must be considered is preventing parasitism through good quality feed, effective management, treatment and epidemiological studies.

The present study demonstrated that GI parasitic infection occur frequently in all three sites where fecal sampling was carried out. However, the number of positive samples having the GI parasites was found the most at site number 5 . The number of fecal samples collected and the number of positive cattle having GI parasites based on the presence of eggs/oocysts in feces using flotation method are summarized in Table 1. 
GASTROINTESTINAL PARASITE INFECTION ON BALI CATTLE RAISED IN SEMI-INTENSIVE FARMING SYSTEM IN DOMPU, SUMBAWA ISLAND: A PRELIMINARY STUDY Made Sriasih, Oscar Yanuarianto, Dahlanuddin, and William Ernest Pomroy

Table 1. Number of cattle detected positive based on age group

\begin{tabular}{ccccccc}
\hline & Total sample & \multicolumn{5}{c}{ Positive sample based on age (month) } \\
\cline { 3 - 7 } & & $\mathbf{0 - 3}$ & $\mathbf{3 - 1 2}$ & $\mathbf{1 2 - 2 4}$ & $\mathbf{2 4 - 3 6}$ & $>\mathbf{3 6}$ \\
\hline Site No. 1 & 22 & 2 & 0 & 4 & 0 & 1 \\
Site No. 4 & 27 & 1 & 3 & 3 & 0 & 1 \\
Site No. 5 & 27 & 9 & 1 & 0 & 6 & 2 \\
\hline Total & $\mathbf{7 6}$ & $\mathbf{1 2}$ & $\mathbf{4}$ & $\mathbf{7}$ & $\mathbf{6}$ & $\mathbf{4}$ \\
\hline
\end{tabular}

Five types of GI parasites, which are Trichuris sp, and Coccidia oocyst, were found Strongyle sp, Toxocara sp, Strongyloides sp, in this study (Table 2).

Table 2. Prevalence of gastrointestinal parasite types and the number of eggs/oocysts per gram feces

\begin{tabular}{clcccc}
\hline $\begin{array}{c}\text { Total } \\
\text { samples }\end{array}$ & GI parasite types & $\begin{array}{c}\text { Total } \\
\text { positive }\end{array}$ & Percentage & Eggs/Oocysts \\
\hline \multirow{6}{*}{76} & Strongyle sp & 14 & 18 & \\
\hline \multirow{2}{*}{ Nematode } & Toxocara sp. & 8 & 11 & $50-250$ \\
& & Strongyloides sp. & 5 & 7 & $50-14800$ \\
& & Trichuris sp. & 3 & 4 & $150-250$ \\
\cline { 3 - 6 } & Coccidia & Oocyst & 18 & 24 & $50-850$ \\
\hline
\end{tabular}

The most common parasite were producing a similar type of egg. The most Coccidia (24\%). The most common nematode numerous type was Toxocara with counts were the Strongyle type (18\%) but this does ranging up to $14800 \mathrm{eggs} / \mathrm{g}$. The GI parasites include a group of closely related species all found were depicted in Fig. 1. 


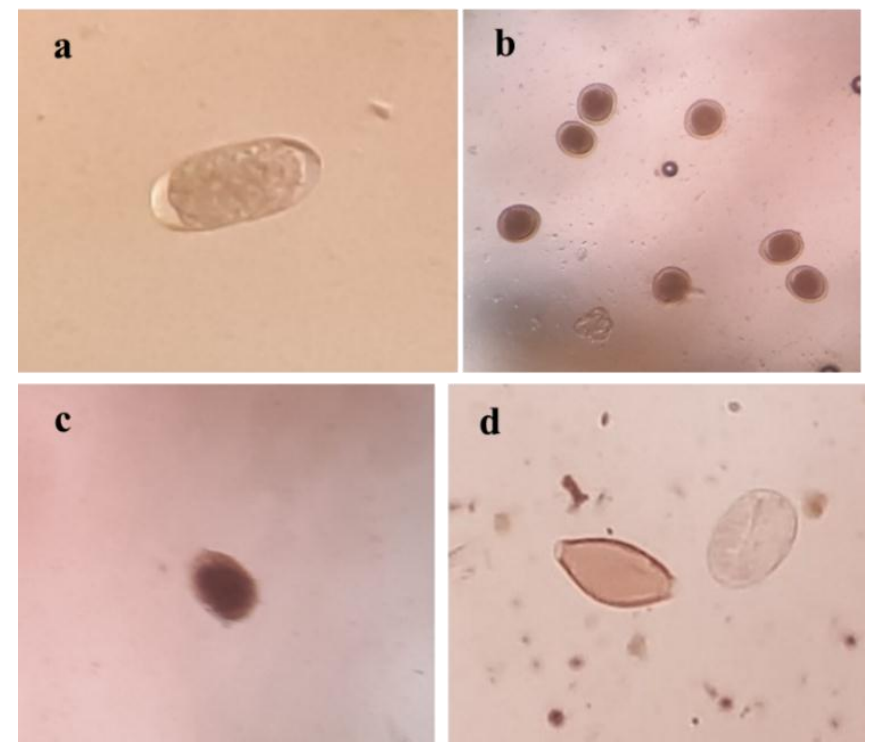

Fig. 1. Gastrointestinal parasite egg types found on fecal samples of Bali cattle a. Strongyle sp; b. Toxocara sp; c. Coccidia oocyst; d. Trichuris sp and Strongyloides sp

Based on parasite type and the number of eggs/oocysts per gram results, this study indicates that protozoan infection was the highest compared to nematode infection. The prevalence of protozoan infections in this study was much lower than that reported by Huang et al. (2014) and Hildreth et al. (2007) with prevalence rates ranging from 80 to $90 \%$. They stated that the high prevalence rate was closely related to moisture level that facilitates the development and transmission of protozoa.

Strongyle sp. and Toxocara sp. are the most common nematode groups found in this study. A number of closely related species which all produce similar eggs are included in this Strongyle count. It is known these are the major causes of parasite infection in many ruminants. Toxocara is found worldwide, but is more abundant in regions with humid tropical or subtropical climate. Studies showed that Toxocariasis was more common in young than adult ruminant (Saraswati et al., 2015; Rast et al., 2013). This study also shows that cattle infected with Toxocara sp. were at a severe infection level with more than 700 eggs (Taylor, 2008).

The prevalence rate of GI parasite infection at site number 5 was the highest compared to other sites (Fig. 2). The prevalence rates at site number 1, 4 and 5 were $31.81 \%, 29.63 \%$ and $66.67 \%$ respectively. 


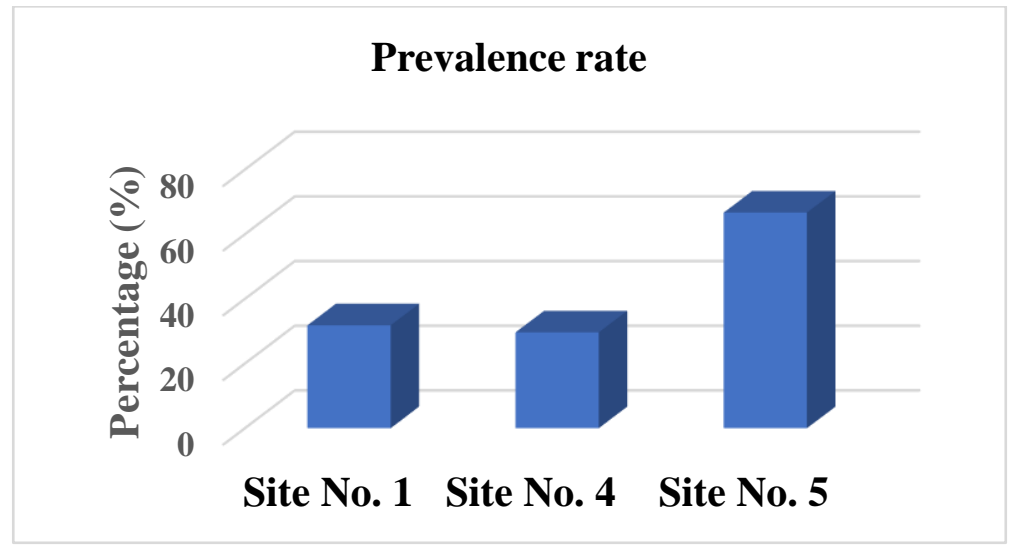

Fig. 2. Prevalence rate of GI parasite infection at 3 locations in Dompu district

Site number 5 is located in Kempo district. This is a low land area (27.4 metres above sea level) whilst other sites are in higher land and this may partly explain this finding. Sharma and Praveen (2017) on their study found that the prevalence of worm infections in low land areas $(57.35 \%)$ is higher than high land areas (42.64\%). The low lands are characterized by a comparatively hot humid environmental situation which is favorable for the survivor of the infective larval stage of most parasites.

In the district scale, the overall prevalence of GI parasitic infection in cattle accounted for $43.42 \%$. This finding is in line with other reports over the last five years from several developing countries with tropical climates (Hamid et al., 2016; Nurtjahyani and Agustin, 2015; Ananta et al., 2014; Tan et al., 2014) that showed the prevalence rate between $11 \%$ and $65 \%$. Different risk factors have been reported to affect the outcome of parasitic infection in cattle. One of the important risk factors that affect high parasitism in tropical areas is the high temperature and humidity that is beneficial for parasite development. The temperature in district of Dompu in the morning ranged from $18-23^{\circ} \mathrm{C}$, while during the day the temperature ranged from $27-30^{\circ} \mathrm{C}$, with an average humidity of $80 \%$. As long as the feces do not dry out these temperatures are close to ideal for development of the free-living infective stages of the parasites that were counted in this study.

Management system of the farm is another risk factor that also significantly contribute to a higher prevalence rate of GI infection. In Dompu district, cattle are reared under traditional farming system with extensive or semi-intensive farming. During the day, cattle are released to the grazing area and are only yarded at night. Cattle maintained with traditional systems (extensive farming) are more at risk of worm infection compared with those that are 
maintained with a more modern (intensive farming) system. On extensive farming, cows are left free to graze or feed themselves on grazing land that may have been contaminated with eggs or worm larvae. Several studies have reported that the performance of grazing cattle in tropical areas is deeply influenced by parasitism (Louvandini et al., 2009;
Strombertg et al., 2012) thus increasing the risk of diseases.

Fig. 3 shows the rate of disease prevalence in three sites of sampling location based on age groups. Amongst age group, young calves of 0-3 months old was more vulnerable in which 12 out of 76 head (15.79\%) were positive.

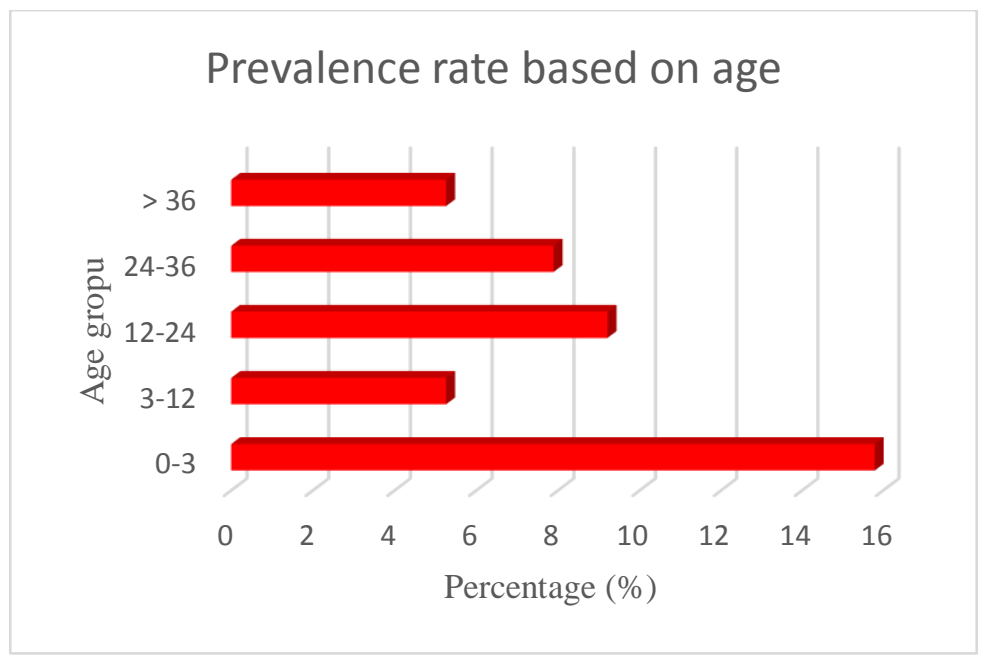

Fig. 3. Prevalence rate of GI parasite infection based on age group.

Worm infections may occur in animals of all age classes, irrespective of practiced management, on almost every farm. Calves, entering their first grazing season, form the age class that is most susceptible to worm infections especially nematode infections. The result of this study shows that young calves (0-3 months old) were more susceptible to GI parasitic infection than older age groups. Widyaningrum et al. (2014) reported that the prevalence of worm infections on Ongole calves under six months of age was higher than calf aged 12 months. In calves under six months, the prevalence rate was $80 \%$ while the older one accounted for $30 \%$.

Gastrointestinal parasite infection in calves will cause growth delayed, weight loss and diarrhea. This may occur because worms in the intestine will reduce the ability to transport glucose and other metabolites. Internal parasite infection can also cause a decrease in physical and immune system conditions so that livestock are very sensitive to disease attacks, which in turn may result in death. 


\section{CONCLUSIONS}

This study shows a considerably high rate of gastrointestinal parasitic infection in Bali cattle raised under semi-intensive farming system, and this preliminary data could be used as a basic data on gastrointestinal parasitic infection in Dompu district. The study also indicated that GI parasites are as common in Bali cattle as other species of cattle. These results may also indicate the need to develop control strategies aiming at lowering the gastrointestinal parasitism.

\section{ACKNOWLEDGEMENT}

We would like to thank the Indonesian Ministry of Research, Technology and Higher Education for the research grant (International Research Collaboration and Scientific Publication scheme, 2018) that enabled us to carry out this research. We also thank IFSCA project of Massey University and Mataram University for any supports given. The authors are also grateful to all farmers involved in this study in Dompu district.

\section{REFERENCES}

Abidin Z. (2002). Penggemukan Sapi Potong. Jakarta: Agro Media Pustaka.

Ananta, S. M., Suharno, A., Hidayat, M., Matsubayashi, M. (2014). Survey on gastrointestinal parasites and detection of Cryptosporidium spp. on cattle in West Java, Indonesia. Asian Pasific Journal of Tropical Medicine, 197201.
Astiti L. G., Panjaitan, T., \& Prisdiminggo. (2011). Identifikasi parasit internal pada sapi Bali wilayah dampingan sarjana membangun desa di kabupaten Bima. Prosiding Seminar Nasional Teknologi Peternakan dan Veteriner, 384-387.

Hamid, P. H., Krsitianingrum, Y. P., Prastowo, J., \& da Silva, L. M. R. (2016). Gastrointestinal Parasites of cattle in Central Java. American Journal of Animal and Veterinary Science, 11(3), 119-124.

Hansen, J. \& Perry, B. (1994). Helminth Parasites of Ruminants A Handbook. The International Laboratory for Research on Animal Diseases. www.fao.org/wairdocs/ILRI/

Hildreth, M. B., Epperson, W. B., \& Mertz, K. J. (2007). Effect of longitude and latitude on fecal egg and oocyst counts in cow-calf beef herds from the United States Northern Great Plains. Veterinary Parasitology, 149, 207212.

Huang, C-C., Wang, L-C., Pan, C-C., Yang, C-H., \& Lai, C-H. (2014). Investigation of gastrointestinal parasites of dairy cattle around Taiwan. Journal of Microbiology, Immunology and Infection, 47, 70-74.

Louvandini, H., Rodrigues, R. R., Gennari, S. M., Mc Manus, C, M., \& Vitti, D. M. S. S. (2009). Phosporus kinetics in calves experimentally submitted to a trickle infection with Cooperia punctate. Veterinary Parasitology, $163,47-51$.

Nurtjahyani, S. D., \& Agustin, D. S. (2015). Comparison of parasite infection degree in cattle (Bos sp.) using fecal egg counting method in two Eat java regions, Lamongan and Gresik. Asian Pacific Journal of Tropical Disease, 5(8), 614-616.

Rast, L., Lee, S., Nampanya, S., Jenny-Ann, L., Toribio, M. L., Khounsy, S., \& Windsor. P. A. (2013). Prevalence and clinical impact of Toxocara vitulorum 
in cattle and buffalo calves in northern Lao PDR. Tropical Animal Health and Production, 45(2), 539-546.

Sarawati, Yunanto, \& Sutawijaya. (2015). Prevalensi Toxocara vitulorum pada sapi Bali di Wilayah propinsi Bali. Buletin Veteriner, 27, 86.

Seo, H. L. S., Filho, L. C. P. M., Honorata, L. A., Da Silva, B. F., do Amarante, A. F. T., \& Bricarello, P. A. (2015). The effect of gastrointestinal nematodes infections level on grazing distance from dung. PLos ONE, 10, 6. Doi: 10.1371/journal.pone.0126340.

Sharma, R. \& Praveen, K. (2017). Most prevalent endoparasitic infestation in domestic ruminants and their management in field condition in Indian scenario: A review. International Journal of Science Environment and Technology, 6(1), 210-216.

Stafford, K. J., West, D. M., \& Pomroy, W. E. (1994). Nematode worm eggs output by ewes. New Zealand Veterinary Journal, 42, 30-32.

Stromberg, B.E., Gasbarre, L. C., Waite, A., Bechtol, D. T., Brown, M. S., Robinson, N. A., et al. (2012). Cooperia punctate: effect on cattle productivity. Veterinary Parasitology, 183, 284-291.

Widyaningrum, Y., Ratnawati, D., \& Sulistya, T. A. (2014). Helminthiasis saluran pencernaan pada pedet sapi Ongole di Loka Penelitian Sapi Potong. Prosiding Seminar Nasional Teknologi Peternakan dan Veteriner, 225-229.

Tan, T. K., Panchadcharam, C., Low, V. L., Lee S. C., \& Ngui, R. (2014). Coinfection of Haemonchus contortus and Trichostrongylus spp. among livestock in Malaysia as revealed by amplification and sequencing of the internal transcribed spacer II DNA region. BMC Vet. Res, 10, 38-38. Doi: 10.1186/1746-6148-10-38.
Taylor, M. A. (2008). Sustainable Worm Control Strategies for Cattle. Agriculture and Horticulture Development Board. www.dairy.co.org.uk 